\title{
PERBANDINGAN NOVEL CANTIK ITU LUKA KARYA EKA KURNIAWAN DENGAN MIDAH SIMANIS BERGIGI EMAS KARYA PRAMOEDYA ANANTA TOER
}

\author{
(Pendekatan Psikologi Sastra)
}

\author{
Runi Fazalani \\ S2 Pendidikan Bahasa Indonesia \\ Pascasarjana Universitas Muhammadiyah Malang \\ runifazalani3@gmail.com
}

\begin{abstract}
ABSTRAK: Tujuan dari penelitian ini adalah untuk mengetahui betapa berpengaruhnya kecanti-kan yang dimiliki oleh seorang perempuan tokoh utama dalam novel Cantik Itu Luka karya Eka Kurniawan dan novel Midah Simanis Bergigi Emas karya Pramoedya Ananta Toer. Kecantikan dapat mengakibatkan keperibadian seseorang merasa terancam. Adapun masalah yang dibahas dalam penelitian ini adalah bagaimana perbandingan pengaruh cantik terhadap tokoh utama perempuan dalam novel Cantik Itu Luka karya Eka Kurniawan dan novel Midah Simanis Bergigi Emas karya Pramoedya Ananta Toer. Penelitian ini menggunakan metode deskriptif kualitatif dengan pemahaman secara mendalam dengan menggunakan pendekatan psikologi sastra. Sumber datanya novel Cantik Itu Luka karya Eka Kurniawan dan novel Midah Simanis Bergigi Emas karya Pramoedya Ananta Toer. Data yang bersumber dari satuan-satuan bahasa yang berupa kutipan cerita. Hasil penelitian menunjukkan pengaruh kecantikan yang dimiliki oleh tokoh utama dalam novel Cantik Itu Luka karya Eka Kurniawan.
\end{abstract}

KATA KUNCI: psikologi sastra, kecantikan dan perempuan.

\begin{abstract}
The objectives of this reseach are how the influence owned by beauty a women the main character in Cantik Itu Luka novel by Eka Kurniawan and Midah Simanis Bergigi Emas by Pramoedya Ananta Toer. The beauty can lead the personality of a feeling person threatened. The as for problem to in this research is how the comparison of the beautiful influence of the main character womwns in the Cantik Itu Luka novel by Eka Kurniawan and Midah Simanis Bergigi Emas by Pramoedya Ananta Toer. This reseach using qualitative descriptive method with deep understanding and the using literature psychology the approach. The source of the data are Cantik Itu Luka novel by Eka Kurniawan dan Midah Simanis Bergigi Emas novel by Pramoedya Ananta Toer. The data source from the language units in the from of story quotes. The research of results show the influence of a beauty possessed by the main character in the Cantik Itu Luka novel by Eka Kurniawan and Midah Simanis Bergigi Emas novel by Pramoedya Ananta Toer.
\end{abstract}

KEY WORDS: literature psychology, beauty and womens.

\section{PENDAHULUAN}

Indonesia terdapat stigma yang
berkembang di masyarakat yang
mengatakan bahwa cantik adalah putih,
Frawisandi (2015, hlm. 1), mengatakan
putih menjadi komoditas yang dijual
belikan sehingga saat ini banyak produk-
produk pemutih kulit yang dipasarkan di
Indonesia. Iklan produk kecantikan
berhasil merepresentasikan bahwa cantik
itu putih, putih itu bersih, bahkan putih itu
sehat. Masyarakat Indonesia diajak untuk
mengubah warna kulitnya yang bukanlah

berkulit putih saja. Syata (2012, hlm. 36) mengemukakan konsep cantik dapat mempe-ngaruhi perilaku masyarakat, misalnya cara seseorang menghargai dirinya dan memandang orang lain. Konsep cantik yang dibatasi hanya sebatas penampilan fisik seperti kulit putih bersih akan sangat merugikan masyarakat.

Kecantikan dapat dibedakan menjadi dua, yaitu kecantikan fisik dan non-fisik atau kecantikan dilihat dari hati. Kecantikan fisik merupakan keindahan dari seorang perempuan yang dapat dilihat dari luar seperti kecantikan rambut, paras 
wajah, kulit dan tubuh, sedangkan kecantikan non-fisik atau kecantikan dalam hati merupakan kecantikan yang tidak dapat terlihat dari fisik atau tidak nyata namun dapat dirasakan, di mana kecantikan tersebut timbul dari hati, sifat dan juga sikap perempuan yang baik, dapat disebut kecantikan batin.

Menurut Hamburg (Santrock, 1996), Salah satu aspek psikologis dari pertumbuhan fisik di masa remaja adalah remaja amat memperhatikan tubuh mereka dan membangun citranya sendiri mengenai tubuh mereka. Perhatian yang berlebihan terhadap citra tubuh atau body image ini, amat kuat pada masa remaja, terutama amat mencolok selama pubertas, saat remaja lebih tidak puas akan keadaan tubuhnya dibandingkan dengan akhir masa remaja. Cross and Cross (Sumartono, 2002), menerangkan mengapa penampilan begitu penting sehingga menimbulkan minat pribadi yang kuat. Menurut remaja, kecantikan dan daya tarik fisik sangat penting bagi umat manusia. Hal ini dikarenakan remaja ingin selalu berpenampilan yang dapat menarik perhatian orang lain terutama teman sebaya. Seperti di novel Cantik Itu Luka karya Eka Kurniawan dengan novel Midah Simanis Bergigi Emas karya Pramoedya Ananta Toer. Novel ini Samasama membahas tentang kecantikan tokoh perempuannya terutama tokoh utamanya yaitu Dewi Ayu yang memiliki fisik yang indah dan menawan apabila di pandang oleh masyarakat dan wajah yang sangat cantik sampai semua lelaki tergila-gila pada dirinya dengan tokoh utama Midah juga memiliki fisik yang sempurna di mata masyarakat dengan kecantikan fisik dan kecantikan yang tumbuh dari dalam hatinya.

Novel Cantik Itu Luka karya Eka Kurniawan dengan novel Midah Simanis Bergigi Emas karya Pramoedya Ananta Toer memuat aspek psikologis, sebagai pengungkapan atau ekspresi jiwa dalam menjalani realita kehidupan sebagai perempuan yang digambarkan melalui tokoh utamanya. Novel ini menceritakan tentang pandangan cantik menurut tokoh utama dan orang-orang di sekitar tokoh utama. Konsep cantik itu sendiri sudah ada takaran, ukuran tersendiri di dalam suatu komunitas, golongan, masyarakat, bahkan negara tertentu. Akan tetapi, karena suatu konsep kecantikanlah akhirnya mengubah kehidupan tokoh utama. Tokoh utama perempuan yang sudah dewasa perempuan yang menjadi tertekan bahkan terganggu secara psikologis yang diawali dari pandangan orang-orang di sekitarnya terhadap tubuh yang terawat dengan baik dan kecantikan yang dimiliki serta penampilannya. Selain itu, diceritakan pula tentang tokoh perempuan dengan berbagai permasalahan kehidupan yang rumit karena kecantikan yang dimiliki oleh tokoh perempuan dalam novel Cantik Itu Luka dan novel Midah Simanis Bergigi Emas,

Masalah kehidupan yang dialami tokoh utama di novel Cantik Itu Luka disebabkan oleh kecantikan yang dimiliki oleh ke empat tokoh perempuan tersebut sehingga ikut diceritakan dengan cukup unik di dalam novel Cantik Itu Luka dan begitu juga dengan novel Midah Simanis Bergigi Emas. Novel ini mengetengahkan beberapa konflik yang ada dalam kehidupan bermasyarakat. Contohnya seorang perempuan yang mempunyai permasalahan dengan kondisi fisik, yang begitu sempurna dan memiliki kecantikan yang alami sehingga membuat semua lakilaki tergila-gila dengan kecantikan yang tokoh perempuan itu miliki, Permasalahan yang dialami tokoh utama, dalam novel Cantik Itu Luka adalah masalah kecantikan yang dimiliki dan menarik untuk dianalisis atau ditelaah. Lingkungan di sekitar kehidupan tokoh utama juga ikut mempengaruhi kondisi kecantikannya dan akhirnya menjadi salah satu faktor pendorong bagi penulis untuk 
menganalisis lebih dalam dengan ilmu bantu psikologi. Ilmu psikologi digunakan sebagai alat untuk menganalisis kondisi kejiwaan dan kecantikan yang dilihat melalui fisik dan batin/jiwanya, terutama tokoh utama dalam novel Cantik Itu Luka karya Eka Kurniawan dan Midah Simanis Bergigi Emas karya Pramoedya Ananta Toer yaitu memiliki kecantikan sangatlah berpengaruh dalam kehidupan sehari-hari dan berdampak negatif bagi masingmasing tokoh utama.

Berdasarkan hasil pemikiran tersebut maka permasalahan yang dapat dirumuskan masalahnya adalah bagaimana perbandingan pengaruh kecantikan tokoh utama dalam novel Cantik Itu Luka karya Eka Kurniawan dengan tokoh utama dalam novel Midah Simanis Bergigi Emas karya Pramoedya Ananta Toer?

\section{METODE PENELITIAN}

Objek penelitian ini adalah dua buah karya sastra yaitu novel Cantik Itu Luka Karya Eka Kurniawan dengan novel Midah Simanis Bergigi Emas Karya Pramoedya Ananta Toer. Adapun faktor yang melatarbelakangi dibandingkannya kedua karya sastra tersebut memiliki kesamaan dari segi kecantikan yang ditampilkan baik dari segi fisik maupun batin, dengan menggunakan pendekatan psikologi sastra.

\section{PEMBAHASAN}

Kecantikan dalam Novel Cantik Itu Luka Karya Eka Kurniawan

Novel Cantik Itu Luka karya Eka

Kurniawan. Menceritakan tentang lima perempuan tokoh utama yang mempunyai kecantikan yang membuat semua laki-laki ingin memilikinya. Kecantikan tokoh utama dilihat dari dua sudut yang pertama kecantikan fisik dan yang kedua kecantikan hati atau kecantikan yang tumbuh dari dalam diri masing-masing tokoh utama.

Kecantikan fisik tokoh utama memiliki dampak masing-masing seperti dibenci oleh kaum perempuan yang ada di desa yang ditempatinya. Kecantikan tokoh utama membuat suami mereka rela melakukan berbagai macam cara untuk memilikinya, seperti tokoh utama Dewi Ayu.

Dewi Ayu ingin memilikinya sendiri dan rela membayarnya berapapun asalkan dia tidak melirik laki-laki lain, seperti yang dikutip oleh peneliti dalam novel Cantik Itu Luka karya Eka Kurniawan.

"Seorang laki-laki tua dengan hidung
menyerupai paruh kakek tua,
berambut keriting keperekan, kulitnya
yang keriput segelap tembaga, dan
terutama cara berjalannya yang sangat
hati-hati seolah semua tulang-
belulangnya akan lepas berhamburan
beritu ia menghentaknya sedikit saja,
Dewi Ayu segera mengenalinya dan
berkata, "kau ketagihan, Pak tua. Kita
bercinta dua malam lalu”, lelaki itu
tersenyum malu, bagaikan.bocah kecil
berjumpa dengan kekasihnya, dan
mengangguk." Aku ingin mati
dipelukanmu." (Eka Kurniawan, 2015,
hlm. 13).

Kutipan di atas menggambarkan betapa cantik paras yang dimiliki oleh Dewi Ayu sehingga orang tua ingin mati dipelukannya.

\footnotetext{
"Si perempuan tetangga melompat masuk dengan keyakinan Dewi Ayu telah berbuat kelewatan.

"dengarlah, pelacur yang telah tidur dengan semua lelaki kami," katanya dengan sedikit dendam." kalau kau mau mati, maka matilah, tapi jangan awetkan tubuhmu”. (Eka Kurniawan, 2015, hlm. 10).
} 
Kutipan di atas adalah dampak kecantikan Dewi Ayu mengakibatkan perempuan-perempuan tetangganya mencacimaki dirinya walaupun dia sudah meninggal.

\begin{abstract}
"Jadi kau sepakat bahwa kau jadi pelacurku seumur hidupmu?" Tanya Maman Gendeng.

Dewi Ayu menggeleng. "Tak selama itu," katanya, "tapi selama kau mampu, terutama uang dan kemaluanmu”. (Eka Kurniawan, 2015, hlm. 126).

"Menyedihkan, "kata sang pelacur. "Kau lelaki ketiga puluh dua yang mencoba memilikiku." (Eka Kurniawan, 2015, hlm. 126).
\end{abstract}

Kutipan selanjutnya menggambarkan tentang betapa cantiknya dewi ayu sehingga tokoh Maman Gendeng ingin memilikinya sendiri dan rela membayar berapapun. Kecantikan Dewi Ayu juga sudah banyak yang ingin memilikinya.

Kecantikan fisik tokoh utama Dewi Ayu yaitu kulitnya lembut dan halus seperti permukaan lilin. Seperti yang telah dikutip oleh peneliti dalam novel karya Eka Kurniawan.

"Dewi ayu mencoba terus mengulurngulur waktu dan berharap sang preman akhirnya datang, dan selebihnya urusan kedua lelaki itu, Shodancho menghampirinya, menyentuh kulit dagunya yang sehalus permukaan lilin." (Eka Kurniawan, 2015:129).

Selanjutnya kecantikan yang dimiliki oleh Alamanda anak Dewi Ayu yang dilihat dari segi fisik yaitu seluruh tubuhnya mengeluarkan cahaya, rambutnya berkilau, wajahnya lembut seperti lilin dan senyumnya manis. Dari sejak kecil Alamanda disukai oleh semua laki-laki semenjak duduk di bangku sekolah dasar sampai dia menikah. Adapun dampak kecantikan yang dimiliki oleh Alamanda membuat laki-laki yang ingin memilikinya rela berbuat tidak baik pada dirinya. Sebagaimana yang telah dikutip oleh peneliti dalam novel Eka Kurniawan.

"Gadis itu baru berumur enam belas tahun, tanpak elok sebagai peranakan campuran. Rambutnya hitam bercahaya, dengan mata kebiruan. Ia mengenakan gaun pengantin dari kain tulle, dengan mahkota kecil yang membuatnya menyerupai peri di buku cerita anak-anak".(Eka Kurniawan, 2015, hlm. 82-83).

Menggambarkan kecantikan yang dimiliki oleh Alamanda yang membuat laki-laki selalu menghayalkan dirinya.

"tak seorang pun di kota ini, dan mungkin di seluruh alam semesta, lebih cantik darinya. Ia lebih cantik daripada Rengganis Sang Putri yang kawin dengan anjing, paling tidak menurutku. Ia lebih cantik dari Ratu laut Kidul. Ia lebih cantik daripada Helena yang membuat Perang Troya meletus. Ia lebih cantik dari Diah Pitaloka yang menyebabkan perang majapahit dan pajajaran. Ia lebih cantik daripada Juliet yang membuat Romeo nekat bunuh diri. Ia lebih cantik dari siapa pun. Seluruh tubuhnya seperti mengeluarkan cahaya, rambutnya lebih mengilau dari sepatu yang baru disemir, wajahnya begitu lembut seolah ia dibuat dari lilin, dan senyumnya seperti mengisap segala yang ada di sekitarnya”.(Eka Kurniawan, 2015, hlm. 165).

Kutipan di atas mencerminkan betapa cantiknya paras yang dimiliki oleh Alamanda anak Dewi Ayu. Sehingga 
membuat laki-laki membayangkan dia sebagai perempuan tercantik sedunia.

Ada juga kutipan yang menggambarkan kecantikan fisik Alamanda yang membuat laki-laki rela menunggu sampai diriny dewasa.

"Ia menunggu sampai Alamanda,
dengan seragam serta tas sekolah,
muncul bersamaan adeknya, Adinda.
Ia akan berjalan menghampiri mereka,
dan menawarkan diri untuk berjalan
bersama keduanya, mengantarkan
sampai sekolah.
"Silakan," kata Alamanda." Aku tak
akan tanggung jawab jika kamu
capek."
Ia melakukannya setiap pagi. Di saat
jam istirahat sekolah, ia berdiri di
bawah pohon sawo di depan kelas,
hanya untuk melihatnya bermain-main
dengan teman-temannya." (Eka
Kurniawan, 2015, hlm. 166).

Kutipan di atas menggambarkan bahwa dengan kecantikan fisik yang dimiliki oleh Alamanda membuat laki-laki rela melakukan apapun demi dia. Sehingga laki-laki itu rela berkorban untuk mendapatkan dirinya.

Adapun dampak kecantikan dirinya yang membuat laki-laki berbuat tidak baik kepadanya dan mengancam keselamatannya, seperti yang telah dikutip oleh peneliti dalam novel Eka Kurniawan.

"jika kau ingin menaklukkan laki-laki dan mencampakkannya, bagai sampah hina, kau salah bertemu denganku. Alamanda aku memenangkan semua perang, termasuk perang melawanmu." (Eka Kurniawan, 2015, hlm. 212).

Kutipan di atas menggambarkan betapa bencinya laki-laki yang di permainkan dan diduakan oleh Alamanda dengan kecantikannya. Laki-laki tersebut menggunakan berbagai macam cara untuk mendapatkan Alamanda.
Kecantikan tokoh utama Adinda anak kedua Dewi Ayu, tidak jauh beda dengan ibu dan kakaknya. Alamanda juga memiliki paras yang cantik dan memiliki tubuh yang putih dan halus, hidung mencuat ramping dan mata yang dihiasi oleh bulu mata yang lentik dan dua kuping bagai dipahat demikian halus dengan bibir yang merengut kecil, dengan pipi berisi. Seperti yang telah dikutip oleh peneliti dalam novel Eka Kurniawan.

"ketika teman-teman si gadis berdatangan dengan penuh kelegaan, secara hati-hati Kamarad Kliwon mendorong gadis itu menjauhkannya dari dirinya, dan pada saat itulah dia bisa melihat satu kecantikan yang unik, satu kecantikan para putri dan bidadari yang lembut dan mistis, tradisional, kuno, alami, dengan rambut yang dikepang dua, dengan mata yang terpejam itu dihiasi bulu mata lentik, dengan hidung yang mencuat ramping berhiaskan dua kuping bagai dipahat demikian halus, dengan bibir yang merengut kecil, dengan pipi berisi, dan pada saat itu lah ia segera menyadari gadis tersebut telah tak sadarkan diri." (Eka Kurniawan, 2015, hlm. 271).

Kutipan di atas menggambarkan sosok tokoh utama Adinda anak dari Dewi Ayu yang memiliki kecantikan yang membuat laki-laki sampai tak bisa berkata apa-apa.

Kecantikan Adinda juga membuat laki-laki datang ke rumahnya untuk melamarnya, seperti yang telah dikutip oleh peneliti dalam novel Eka Kurniawan.

\footnotetext{
"Selamat siang, nyonya," kata Kamared Kliwon.

"Selamat siang. Aku bertanyatanya kepada kau tidak mati dieksikusi," kata Dewi Ayu. "Sebab mereka tahu kematian terlalu menyenangkan untukku."
} 


\begin{abstract}
Dewi Ayu tertawa kecil mendengar nada ironi dalam kalimatnya. "Apakah kau ingin segelas kopi buatan anak gadisku, Kamared? Kudengar kalian begitu akrab di tahun-tahun terakhir."

"Anak gadis yang mana. Nyonya?"

"Hanya tertinggal satu. Adinda."

"Ya. Terima kasih, Nyonya. Aku datang untuk melamar Adinda."
\end{abstract}

Kutipan di atas menggambarkan betapa cantik fisiknya Adinda sehingga seorang laki-laki berani datang kerumahnya dan melamarnya secara langsung kepada Dewi Ayu.

Kecantikan tokoh utama yang keempat adalah Maya Dewi. Dia juga tidak kalah cantiknya dengan ibunya yaitu Dewi Ayu dan kakak-kakaknya Alamanda dan Adinda. Sebagai mana di jelas kan dalam novel Eka Kurniawan. Kecantikan Maya Dewi yang di lihat dari fisiknya seperti, rambutnya hitam mengilau, matanya yang jernih, hidung dan bibirnya yang begitu indah. Seperti yang telah dikutip oleh peneliti dalam novel Eka Kurniawan.

"Ia memandang wajah gadis kecil itu dengan tatapan seorang lelaki yang melihat kekasihnya mati, mengakui kecantikan kecilnya begitu mempesona, satu hal yang ia tak pernah perhatikan sebelumnya. Rambutnya hitam mengilau, mengembang dibawah kepalanya di atas permukaan bantal. Matanya yang balas menatap dirinya begitu jernih dan kekanak-kanakan. Hidung dan bibirnya dan segalanya begitu menakjubkan". (Eka Kurniawan, 2015, hlm. 254).

Dalam kutipan di atas menggambarkan begitu sempurna kecantikan fisik yang dimiliki oleh Maya Dewi anak dari Dewi Ayu.

Terakhir tokoh utama Cantik anak Dewi Ayu. Tokoh utama Cantik berbeda dari ibu dan saudaranya. Dia terlahir sebagai gadis yang buruk rupa karena Dewi Ayu tidak pernah menginginkannya lahir kedunia. Bermacam cara dilakukan Dewi ayu untuk membunuhnya dalam kandungannya tetapi tidak dapat dibunuh, seperti yang telah dikutip oleh peneliti dalam novel Eka Kurniawan.

"Dewi ayu telah mencoba membunuhnya, ketika tahu bahwa ia bunting, tak peduli setengah abad ia telah hidup, pengalaman mengajarinya bahwa ia bunting lagi, Sebagaimana anak-anaknya yang lain, ia tak tahu siapa ayahnya. Namun berbeda dengan yang lain, ia sama sekali tak mengharapkan hidup. Maka ia menelan lima butir parasetamol yang ia peroleh dari seorang mantri, diminum dengan setengah liter soda, cukup untuk nyaris membunuhnya. (Eka Kurniawan, 2015, hlm. 5).

Tokoh utama Cantik adalah anak terakhir Dewi Ayu yang tidak diinginkan oleh Dewi Ayu dan bermacam cara ingin membunuhnya. Karena bagi Dewi Ayu kecantikan yang dimilikinya dan anakanaknya mengakibatkan luka yang begitu mendalam.

Kecantikan yang timbul dari dalam hati atau kecantikan batin tokoh utama dalam novel Cantik Itu Luka karya Eka kurniawan dapat dilihat dalam kutipan yang telah peneliti teliti dalam novel Eka Kurniawan yaitu.

"Dewi Ayu merayakan natal tahun itu untuk menghibur Gerda. Ia mencari ranting pohon beringin yang tumbuh di depan gerbang kamp, menghiasinya dengan potongan-potongan kertas, dan menyanyikan Jinggle Bells. Ia sendiri dibuat heran dengan perilaku religiusnya, ia tapi ia sangat bahagia di waktu-waktu itu dengan memiliki Ola dan Gerda, tak peduli betapa tak menyenangkannya menghabiskan waktu 
di kamp tahanan”. (Eka Rukriawan, 2015, hlm. 70-71).

Kutipan di atas menggambarkan betapa mulia hatinya Dewi Ayu yang memperhatiak anak yatim piatu dan tidak peduli dia tidak mempunyai ikatan darah dengan mereka.

"kita tidak akan kelaparan," kata Dewi Ayu. "selain lintah, masih ada tokek. Cicak dan tikus."

"terima kasih," jawab mereka segera." (Eka Kurniawan, 2015, hlm. 63).

Tokoh Dewi Ayu rela melakukan apapun demi keselamat mereka semua. Sampai memasakkan makanan untuk semua penghuni tahanan walapun dia tidak mengenalinya.

"Dewi Ayu yang telah melangkah berdiri di hadapannya hanya terpisah oleh meja. "Aku gantikan gadis yang tadi, Komandan. Kau tiduri aku tapi beri ibunya obat dan dokter. Dan dokter!" (Eka Kurniawan, 2015, hlm. 67).

Tokoh Dewi Ayu merelakan kehormatannya untuk menyelamatkan nyawa seorang ibu, untuk mendapatklan obat dan seorang dokter dari kolenial tentara jepang.

"Gadis itu menemukan jahitan yang lepas di pakaian seragamnya. Tanpa malu-malu sementara saat itu Sang Shodancho sedang berbincang dengan Dewi Ayu ibunya. Alamanda berkata, "Jahitan bajumu lepas, Shodancho. Jika tak keberatan akan aku jahitkan untukmu." (Eka Kurniawan, 2015: 207).

Kutipan di atas menggambarkan betapa mulia hatinya Alamanda rela menjahitkan baju seseorang yang tidak ia sukai. "hanya Alamanda yang tampaknya masih memiliki kekuatan untuk menghentikan pembunuhan laki-laki tersebut: perempuan itu memegang kuncinya."(Eka Kurniawan, 2015, hlm. 327).

Kutipan di atas menggambarkan ketulusan hati Alamanda menolong mantan kekasihnya untuk tidak bunuh oleh orang dibencinya dan merelakan dirinya sebagai jaminan.

"Aku, akan berhenti sekolah,” kata
Maya Dewi suatu ketika, mengejutkan
Maman Gendeng, Waktu itu Maya
Dewi telah menjelang berumur tujuh
belas tahun. Alasannya sangat tegas
dikatakan Maya Dewi, bahwa ia ingin
mengurus rumah dan suaminya
dengan lebih baik." (Eka Kurniawan,
2015, hlm. 325).

Kutipan di atas menggambarkan ketulusan hati Maya Dewi untuk mengabdi kepada suaminya dan rela meninggalkan sekolahnya demi mengurus rumah tangga dan suaminya.

Kecantikan yang dimiliki oleh tokoh utama Adinda dapat dilihat dari keihlasannya dirinya meminta maaf kepada pacar kakaknya untuk tidak mengutuk kakaknya. Seperti yang peneliti kutip dalam novelnya Eka Kurniawan yaitu.

"ia datang di suatu sore, memohon dengan sangat kepadanya.

"jangan kau sakiti kakakku," katanya, nyaris menangis, "ia telah cukup menderita kawin dengan Shodancho itu."

"Aku tak melakukan apa pun."

"Kau mengutuknya agar kehilangan anak."

"Itu tidak benar," kata kamared Kliwon membela diri." Aku hanya melihat perut kakakmu dan aku mengatakan apa yang aku lihat." 
Gadis itu sama sekali tak percaya. Ia duduk ditempat biasanya ia duduk ia membaca buku, campur aduk antara marah dan kebingungan. Biasanya Kamarud Kliwon akan pergi meninggalkannya, namun kali ini ia dengan tak berdayanya menarik kursi dan duduk di depannya. Tak ada siapa pun sore itu kecuali mereka berdua, bersama cicak di dinding, dan labalaba yang bergelantungan membangun jerat.

"Kumohon, Kamarud, lupakan Alamanda."

"Aku bahkan telah lupa itulah namanya."

Adinda mengabaikan humor yang tak lucu tersebut." Jika kau marah padanya, "ia berkata. " lampiaskanlah dendammu padaku." "baiklah aku akan iris-isris seperti tomat," kata Komarud Kliwon dalam usaha sia-sia menenangkan gadis itu.

"kau boleh membunuhku jika mau." (Eka Kurniawan, 2015, hlm. 276).

Kutiapn di atas menggambarkan betapa cantiknya hati Adinda merelakan dirinya dibunuh untuk menolong kakaknya, dan melakukan berbagai macam cara untuk menolong saudaranya dari kutukan mantan pacarnya.

\section{Kecantikan dalam Novel Midah Simanis Bergigi Emas Karya Pramoedya} Ananta Toer.

Sedangkan novel Midah Simanis Bergigi Emas karya Pramoedya Ananta Toer. Menceritakan tentang tokoh utama perempuan yang mempunyai kecantikan yang membuat semua laki-laki ingin memilikinya. Kecantikan tokoh utama dilihat dari dua sudut yang pertama kecantikan fisik dan yang kedua kecantikan hati atau kecantikan yang tumbuh dari dalam diri tokoh utama.

Kecantikan dari segi fisik yang telah di teliti oleh peneliti dalam novel Midah Simanis Bergigi Emas karya
Pramoedya Ananta Toer dapat dilihat dalam kutiapan yang sudah peneliti kutip sebagai berikut.

"nama tokoh utama itu midah. Pendek sekali namanya. Hanya midah. Kulitnya kuning. Wajahnya agak bulat. Kalau senyum, ih manisnya. Cantik parasnya, lentik suaranya, kuat hatinya." (Pramoedya, 2009, hlm. 05).

Kutipan ini menggambarkan betapa cantiknya Midah dan fisiknya begitu sempurna. Dengan kulit indahnya dan senyum yang menawan dapat memikat hati seorang laki-laki.

"Midah begitu manis dan montok dan tujuh atau delapan tahun lagi dia akan menguasai hati-muda diseluruh daerah Cibatok." (Pramoedya, 2009, hlm. 09).

Kutipan di atas menggambarkan kecantikan midah yang belum berumur tujuh tahun sudah memiliki kecantikan yang sangat sempurna. Sehingga bisa memikat seluruh laki-laki yang ada di kampung ayahnya yaitu di daerah Cibatok.

"sore hari ia pulang kembali ke rumah di antara anaknya si Midah dan bininya. Sudah dapat ditentukan ia duduk dikursi goyang sambil mendengarkan piring hitam yang membawakan suara Umi Kalsum kepadanya. Juga sudah dapat ditentukan Midah duduk di pangkuannya dan ia mengelus pipinya yang montok sambil merestui selamat dalam hatinya." (Pramoedya, 2009, hlm. 11).

Dalam kutipan ini menggambarkan sosok tokoh utama Midah memiliki pipi yang montok. Dengan kecantikannya Midah sangat dijaga oleh kedua orangtunaya. 
"Kehinaan? Menjual diriku?

Ya.

Midah tersenyum. Giginya putih gemerlap.

Ah-ah, itulah yang aku takuti. Dengan senyummu itu runtuhlah iman yang melihatmu.

Midah menyeka senyumnya dengan tangan. Dan ia menggelengkan kepala." (Pramoedya, 2009, hlm. 25).

Dalam kutipan di atas di gambarkan sosok kecantikan yang dimiliki Midah dengan senyumnya saja dapat meluluhkan hati laki-laki. Sehingga pembantunya sendiri takut dengan senyumnya yang begitu indah.

"Sekali ia tersenyum, dan senyum itu di sambut oleh Min dengan wajah merah membara. Tetapi pemuda itu tak juga mendekatinya untuk membuka percakapan. Akhirnya keduanya berpandang-pandangan begitu lama, sehingga pemuda Min lupa pada makanan yang ada di depannya." (Pramoedya, 2009, hlm. $31)$.

tokoh utama di atas menggambarkan kecantikannya dengan senyum manisnya yang membuat laki-laki itu lupa dengan makanan yang telah ia pesan dan sekali senyuman saja seorang laki-laki menjadi lupa segalanya.

"Situkang gendang yang ada di sampingmu itu Dul Gendang. Habis perkara. Dan karena engkau begini manis-memang cocok pantun Min tadi. Engkau memang manis. Jadi kami sebut saja Manis." (Pramoedya, 2009, hlm. 35).

\section{Dalam kutipan di atas} menggambarkan kecantikan tokoh utama Midah, dengan wajah yang manis dia dipanggil si Manis oleh gerombolan pengamen yang baru saja dia kenal, dan
Midah mulai mengikutinya bernyanyi di jalanan.

"Kini ia berhadapan dengan tenaga gila yang dibuat darah yang sedang mendidih. Ia melawan, tetapi percuma. Akhirnya berbisik lemah jangan ganggu aku. Aku sedang mengandung.

Tetapi Mimin tidak peduli. Tubuhnya telah terguncang-guncang oleh terkeman itu.

Jangan ganggu aku! Simanis mengeraskan cegahannya. Aku sedang mengandung!

Keriuhan dalam kamar lenyap. Tetapi mimin tetap mengamuk." (Pramoedya, 2009, hlm. 40).

Dalam kutipan di atas menggamabrkan kecantikan tokoh utama Midah berdampak pada keselamatannya dan kehormatannya sehingga seorang lakilaki ingin berbuat tidak baik kepadanya meskipun dia sedang mengandung.

“jangan menangis-siapa namamu?

Panggil dia Simanis, tuan polisi! Sambut kepala rombongan. Ia tak pernah membilangkan namanya yang sesungguhnya.

Simanis. Ya, sesungguhnya engkau memang manis.jangan takut besok aku datang kemari lagi untuk melihat." (Pramoedya, 2009: 61).

Kutipan di atas menggambarkan betapa mempesonanya tokoh utama sehingga pak polisi juga kagum dengan kecantikan yang dimilikinya.

“Tiru-tiru pake gigi emas. Tidak laku gigimu itu! Teriak pada Nini.

Mengapa dia tidak juga diusir? Tanya orang-orang lain pada kepala rombongan.

Aku punya biola, Mimin punya gendang, semua orang di rombongan punya alatnya sendiri-sendiri. punya apa kau? 
Betina begini mesti diusir.

Manis, kata kepala rombongan itu akhirnya. Dengan gigi emasmu itu engkau bertambah manis. Sayang tak mau jadi biniku. Jadi.......

Baiklah. Baiklah. Aku mengerti. Kata midah akhirnya. Dan sambil membawa anak dan buntalan po serta pakaiannya ia tinggalkan penginapan itu.

Ia sendiri tak tahu ke mana harus pergi. Tapi ia harus pergi dan ia pun pergilah." (Pramoedya, 2009, hlm. 65).

Tidak hanya Kecantikan yang disukai oleh banyak lelaki akan tetapi suaranya yang indah membuat dia menjadi terkenal. Seperti yang sudah peneliti kutip di dalam novel Midah Simanis Bergigi Emas.

"Sekali waktu tetangganya berlarilarian menemuinya.

Kemudian:

Ayolah kalau tidak percaya. Ayolah. Dan ditariknya perempuan itu diajak ikut mendengarkan radio.

Dan kedua perempuan itu mendengarkan.

Engkau dengar? Itu adalah suara anakmu. Aku tak bimbang. Aku pernah dengar anakmu menyanyinyanyi itu.

Dengarkan”.

Kutipan di atas menggambarkan indahnya suara tokoh utama sehingga suaranya dikenal oleh ibunya dan tetangganya sehingga dia menjadi penyanyi yang terkenal dengan kecantikan suaranya dan kecantikan fisiknya.

Kutipan di atas menggambarkan betapa besar dampak kecantikannya. Midah sangat dibenci oleh rekan-rekannya dan ketua rombongannya karena menolak lamaran ketua rombongan.

"Hadji Terubus itu memang bangsat, kembali ia kehilangan kendali. Anakku juga begitu cantik, begitu manis-tidak mungkin! Kalau dia tak kejam, tidak mungkin dia lari. Tidak mungkin dia jadi penyanyi." (Pramoedya, 2009, hlm. 100).

Kutipan di atas menggambarkan betapa tersiksanya Midah dengan kecantikan yang dimilikinya, sehingga dia dijadikan istri ke empat oleh suaminya. Pada saat Midah tau dirinya di jadikan istri ke empat Midah langsung kabur dari rumah suaminya dan dia menjadi penyanyi di radio dengan wajah cantiknya dan suaranya yang indah.

Kecantikan yang timbul dari dalam hati atau kecantikan batin tokoh utama dalam novel Midah Simanis Bergigi Emas karya Pramoedya Ananta Toer dapat dilihat dalam kutipan yang telah peneliti teliti dalam novel Pramoedya Ananta Toer yaitu.

"Midah dilahirkan di tengah keluarga
yang ta'at beragama. Hadji Abdul
nama bapaknya. Fanatic terhadap
musik-musik berbau Arab. Umi
Kalsum-bukan inul-yang menjadi
penyani favoritnya. Sampai ketika usia
9 tahun kehidupan Midah sangat
enak." (Pramoedya, 2009, hlm. 06).

Kutipan di atas menggambarkan betapa cantiknya hati Midah yang selalu dididik dengan keadaan keluarga yang agamais. Dengan keluarga yang begitu fanatik dengan kehidupan yang berbau kekinian dari mulai musiknya sampai ketaatan beribadah.

\footnotetext{
"Walaupun ia hanya menjadi penyanyi dengan panggilan simanis bergigi emas dalam kelompok pengamen keliling dari satu resto ke resto lainnya, bahkan dari pintu kepintu rumah warga. Dengan kandungan yang makin membesar dari hari ke hari, Midah tampak kelelahan. Tapi manusia tidak boleh menyerah pada kelelahan. Hawa kehidupan jalanan yang liar dan ganas
} 
harus diarungi." (Pramoedya, 2009, hlm. 07).

Kutipan di atas menggambarkan betapa cantik hati Midah karena rela hidup dijalanan demi anak yang dia kandung. Dengan kebesaran hati dia merelakan semuanya supaya anak yang dikandungannya dapat hidup dan bertahan. Midah tidak pernah mengeluh dengan apa yang dia kerjakan.

"Tuhan kembalikan anakku padaku dalam keadaan seperti waktu ia meninggalkan rumah kami suci dan manis, cantik dan baik budi." (Pramoedya, 2009, hlm. 99).

Kutipan di atas mencerminkan betapa mulia hati Midah dan mempunyai budi pekerti yang baik. Sehingga orang tuanya sangat sayang pada dirinya pada saat Midah mendapatkan musibah dalam hidupnya yang di tanggung sendiri.

\section{"lambat-lambat ia bangkit. Hatinya mendoakan keselamatan abadi untuk anaknya yang sedang disuapi neneknya. Kakinya dengan bimbingan melangkah ke gapura pagar, kemudian ia menengok ke arah rumah orangtuanya dan berhenti lagi. Lama ia berhenti." (Pramoedya, 2009, hlm. 127).}

Kutipan di atas menggambarkan kecantikan yang timbul dalam hati tokoh utama Midah. Midah rela pergi dari rumah orang tuanya untuk menjaga kehormatan keluarganya. Karena Midah sedang mengandung anak dari hubungannya yang tidak sah. Dia takut keluarganya dihina oleh tetangga dan warga kampung.

\section{Perbandingan Kecantikan Tokoh Utama Novel Cantik Itu Luka Karya Eka Kurniawan dengan Novel Midah Simanis Bergigi Emas karya Pramoedya Toer.}

Perbandingan kecantikan tokoh utama novel Cantik Itu Luka Karya Eka Kurniawan dengan Novel Midah Simanis Bergigi Emas karya Pramoedya Toer adalah. Tokoh utama novel Cantik Itu Luka Karya Eka Kurniawan tidak terlalu di jelaskan secara terperinci oleh pengarang dan dapat dijabarkan jika tokoh utamanya memiliki kecantikan yang relative karena tokoh utamanya adalah keturunan orang belanda yang memiliki kulit putih dan lembut selembut lilin dan matanya yang kecoklatan seperti khas orang belanda dan kecantikan hati atau batin yang dimiliki oleh tokoh utama dalam novel ini biasa karena tokoh utama Dewi Ayu ingin membunuh anaknya. Kulitnya sehalus permukaan lilin. Rambutnya hitam bercahaya. Mata kebiruan, tajam dan indah, Parasnya cantik melebihi tuan putri di seluruh dunia Tubuhnya mengeluarkan cahaya. Tradisional, kuno seperti kecantikan terdahulu yang alami tanpa polesan Bulu matanya lentik Senyumnya manis, bibirnya kecil, pipinya berisi, hidungnya mancung, parasnya cantik melebihi tuan putri di seluruh dunia. Kecantikan dilihat dari batin selalu menolong orang walaupun dia tidak mengenalnya, merelakan keperawa-nannya dan kehormatannya untuk menolong nyawaseorang ibu, menolong orang tanpa pamrih dan merelakan segala. Sedangkan kecantikan tokoh utama novel Midah Simanis Bergigi Emas karya Pramoedya Toer adalah perempuan yang berasal dari jawa dan memiliki kecantikan tradisional dan alami, kulitnya kuning, wajahnya agak bulat, senyumnya manis, parasnya cantik, lentik suaranya, montok tubuhnya, pipinya montok, giginya putih dan dia menggunakan gigi emas. Kecantikan batin yang dimilikinya yang penuh dengan pengorbanan kepada anaknya walaupun anak yang tidak diakui oleh ayahnya, taat beragama, hatinya lembut, baik budi, tidak 
FON : Jurnal Pendidikan Bahasa dan Sastra Indonesia

Volume 14 Nomor 1 Tahun 2019

sombong, selalu menjaga kehormatan keluarga.

\section{KESIMPULAN}

Pengaruh kecantikan yang di dimiliki oleh tokoh utama dalam novel Cantik Itu Luka karya Eka Kurniawan, membuat hidup tokoh utama dan kehidupan anak-anaknya mendapatkan dampak yang sangat tidak diinginkan. Akibat kecantikan yang dimilikinya semua tetangga mencaci maki dan membicarakannya. Tidak hanya tetangganya yang membencinya akan tetapi, orang yang ingin memilikinya berbuat tidak baik kepadanya ada yang dendam dan rela melakukan apapun demi mereka. Sebagian ada yang memuji kecantikannya sehingga bersedia membayar berapapun demi mereka. Bukan hanya tokoh utama Dewi Ayu saja yang mendapatkan ketidak sukaan akan tetapi seluruh keluarganya. Sedangkan tokoh utama novel Midah Simanis Bergigi Emas akibat kecantikannya banyak yang suka kepada dirinya. Kecantikan yang dimiliki oleh tokoh utama ini mengakibatkan lelaki ingin memilikinya dan menikahinya walaupun lelaki itu mempunyai istri banyak. Akibat kecantikannya pula tokoh utama ingin di perkosa oleh laki-laki walaupun tokoh utama sedang hamil. Pengaruh kecantikan yang dimilikinya sangat besar kepada kehidupnya sehari-hari sampai tokoh utama menjadi terkenal dengan suaranya yang merdu dan wajahnya yang cantik rupawan. Kecantikan fisik mempengaruhi hidupnya dan kecantikan batin pula membuat tokoh utama kuat bertahan dan dengan ketulusan hatinya pula dia rela meninggalkan semuanya untuk menjaga kehormatan keluarganya. Kecantikan itu hanya sementara dan tidak akan pernah kekal di dunia ini dan kecantikan akan dilihat oleh orang dari segi positif dan negatifnya.

\section{DAFTAR PUSTAKA}

Frawisandi. (2006). Tubuh Dalam Budaya. Jokjakarta: Liks pelangi aksara.

Siswanto. (2005). Metode Penelitian Sastra: Analisis Psikologi. Yogyakarta: Muhammadyah University Press.

Zaimar, Okke, K.S. (2003). Psikoanalisis dan Analisis Sastra. Depok: Pusat Penelitian Kemas-yarakatan dan Budaya Lembaga Penelitian Universitas Indonesia.

Endraswara, Suwardi. (2003). Metodologi Penelitian Sastra. Jogjakarta: Pustaka Widyatama.

Eka Kurniawan. (2015). Cantik Itu Luka. Jakarta: PT Gramadia Pustaka Utama.

Rizkiasari, A. O. (2016). Konflik Psikologis Tokoh Perempuan Dalam N Cantik Itu Luka Karya Eka Kurniawan. Bahasa Dan Sastra Indonesia-S1, 5(6).

Nurhayati, H. (2008). Aspek Kepribadian Tokoh Utama Dalam Novel Midah, Simanis Bergigi Emas Karya Pramoedya Ananta Toer: Tinjauan Psikologi Sastra (Doctoral dissertation, Universitas Muhammadiyah Surakarta). 